\title{
Circular Economy versus Planetary Limits: A Slovak Forestry Sector Case Study
}

\author{
Andreas Beckmann \\ Regional CEO, World Wide Funds Central and Eastern European \\ abeckmann@wwfcee.org
}

Uthayasankar Sivarajah*

University of Bradford, School of Management Richmond Road, Bradford BD7 1DP, United Kingdom u.sivarajah@bradford.ac.uk

\author{
Zahir Irani \\ University of Bradford School of Management \\ Richmond Road, Bradford BD7 1DP, United Kingdom \\ z.irani@bradford.ac.uk
}




\begin{abstract}
Purpose: Circular economy is presented as an approach to economic growth that is in line with sustainable development. However, recent literature has highlighted the limits of the concept in terms of environmental sustainability. The study examines the relationship between circular economy and conservation of ecosystems, using a case study on the implications of a circular economy for Slovak forests and forest sector.

Design/methodology/approach: This study adopts a qualitative methodology through a focused review of relevant literature on circular economy and sustainable development and primary data gathered through semi-structured interviews with 15 experts and practitioners in the forest sector, forest conservation and circular economy context, both from within as well as outside of Slovakia.
\end{abstract}

Findings: The study finds that the forestry sector has an important role to play in a shift to a circular economy in Slovakia, with significant opportunities for improved efficiency as well as substitution of wood for non-renewable resources. There is also growing potential for ecosystem stewardship and restoration. However, the increased application of biomass could crowd out other needs, including for biodiversity. Safeguarding these services depends ultimately on good governance.

Originality/value: The study highlights that circular economy taken in a narrow focus on resource efficiency is insufficient to ensure environmental sustainability but rather needs to be set within the broader environmental and social context.

Keywords: biodiversity, circular economy, forestry, Slovakia, sustainability, planetary boundaries

Article classification: Research Paper 


\section{Introduction}

The concept of the circular economy goes back decades, but has gained considerable attention in recent years, touted particularly by the European Union, governments and companies as an answer to problems of resource scarcity, waste, economic development, employment as well as environmental challenges (Winans et al. 2017; Ghisellini et al. 2016). The circular economy could yield over $€ 600$ billion per year to European economies and generate an additional $€ 1.2$ trillion in non-resource and externality benefits that together could boost GDP by 7\% (EMF 2015a). At the same time, by extension, circular economy is presented as an answer to broader challenges of sustainability that are coming into sharp focus as the defining challenge of the $21^{\text {st }}$ century (OECD 2012). For many, circular economy promises a new model of economic development that is sustainable in the fullest sense of the word, i.e. sustainable without destroying the ecosystems on which the economy itself -- and our civilization more generally -- depends.

Can we have our cake and eat it too -- can circular economy ensure sustainable economic development while ensuring we remain within our planetary boundaries? The intervention question for this study is to what extent the circular economy concept contributes to environmental (and by extension economic) sustainability. In particular, can a circular economy in the Slovak forest sector ensure the long-term conservation of forest habitats and related ecosystem goods and services in Slovakia? This study presents a case study supporting recent investigations of Korhonen et al (2018) and others (e.g. Desing et al. 2020) into the relevance of circular economy to achieving broader environmental sustainability.

Forestry presents a useful focus for such an investigation. Forests cover $31 \%$ of the Earth's land surface and are an important source for livelihoods and critical ecosystem goods and services, from biodiversity to climate regulation (WWF 2011). Timber is a renewable resource, so the forest sector is often given as an example of circular economy. Despite this, only limited research has been done on the forest industry in a circular economy context. Indeed, Winans (2017) points out the critical research gap in circular economy application to biological systems. Some studies describe industrial ecologies of the paper and pulp industry (Sokkla et al. 2011; Pakarinen et al. 2010; Li \& Ma 2015), but only a handful treat circular 
economy in terms of the broader forest sector (Sitra 2016a, 2016b; CEPI 2011; Mabee 2011).

Given its limited size and complexity, in geographical as well as economic and social terms, Slovakia provides a manageable focus for such an investigation. Slovakia is relatively small (49,032 $\mathrm{km}^{2}$; population 5.43 million), with a simple landscape structure dominated by temperate and alpine forests. Focusing on Slovakia also contributes to exploring uncharted territory. Academic investigations into circular economy have focused especially on China, Western and Northern Europe, North America, Australia, Japan and to a much lesser extent Africa and Latin America (Ghisellini et al. 2016). In terms of academic interest in circular economy, Slovakia and other countries of Central and Eastern Europe appear to be virtually untouched - a recent review of 500 studies related to circular economy found four related to Poland and apparently none in other countries of the region (Merli et al. 2018). So, in addition to providing a convenient focus for appraising circular economy theory, an examination of circular economy in the Slovak forest sector also contributes to filling significant knowledge gaps.

In turn, a circular economy has become of interest for the Slovak government and key stakeholders as a response to global and EU policy developments and as potential solution for addressing economic, social and environmental challenges (Slovak Ministry of Environment 2020) With regard to the country's forest sector in particular, contributing concerns include the long-term security of supply of wood in the face of climate change as well as declining biodiversity (WWF-DCP 2019).

Circular economy is presented as an approach to economic growth that is in line with sustainable environmental and economic development (EMF 2013a). However, Korhonen et al. (2018) and other scholars (Andersen 2007; Allwood 2014; Murray et al. 2015) have highlighted the limits and challenges of the circular economy concept in terms of environmental sustainability and called for a more integrated approach that places circular economy more explicitly within the broader perspective of planetary boundaries and ecosystem goods and services. This study highlights the relevance of these arguments on the example of the Slovak forest sector, concluding that circular economy presents significant opportunities but also challenges for Slovak forests. The study is based on a review of circular economy literature including secondary sources from Slovak authorities and 
primary qualitative data gathered through 15 semi-structured interviews with relevant experts to fill in knowledge gaps and collect opinions. This case study of the Slovak forest sector contributes to the normative literature on circular economy and forestry sector in suggesting that the circular economy must be placed in a broader context, one that integrates environmental and social systems.

\section{Literature Review}

\subsection{Development and application of the circular economy concept}

The concept of the circular economy goes back decades, but only recently has it attracted widespread attention (Winans et al. 2017; Murray et al. 2015). The Chinese government has applied the concept in national policy since the mid-2000's (Yuan et al. 2006; Lieder and Rashid 2016), followed by the European Commission (European Commission 2015) and a growing list of countries, including Finland and Slovenia (Sitra 2016b; Godina 2016). The concept is also gaining currency in the private sector, promoted by global giants like Renault, Google, Phillips and Kingfisher as well as entrepreneurs (EMF 2013a; Kingfisher 2013). Academic publications on circular economy are growing rapidly (Merli et al. 2018). Reflecting this dynamic development, circular economy does not have a single definition and is still evolving. The term has been associated with a range of interpretations by different authors (Murray et al. 2015). The table 1 highlights some of the noteworthy circular economy definitions discussed in the extant literature.

\begin{tabular}{|c|c|c|}
\hline Circular Economy Definition & Emergent Themes & Reference \\
\hline $\begin{array}{l}\text { The central idea is to close material loops, reduce } \\
\text { inputs, and reuse or recycle products and waste to } \\
\text { achieve a higher quality of life through increased } \\
\text { resource efficiency. }\end{array}$ & $\begin{array}{ll}\text { - } & \text { Close material loops } \\
\text { - } & \text { Reduce inputs } \\
\text { - } & \text { Reuse } \\
\text { - } & \text { Recycle } \\
\text { - } & \text { Resource efficiency }\end{array}$ & (Peters et al., 2007) \\
\hline $\begin{array}{l}\text { The ability to overcome current environmental } \\
\text { and resource management problems while } \\
\text { achieving improvements in resource productivity } \\
\text { and eco- efficiency. The circular economy is } \\
\text { understood to mean the realisation of a closed } \\
\text { loop of material flows in the Chinese economic }\end{array}$ & $\begin{array}{l}\text { - Improvement in resource } \\
\text { productivity and eco- } \\
\text { efficiency } \\
\text { - Closed loop material flow }\end{array}$ & $\begin{array}{l}\text { (Geng and Doberstein } \\
\text { 2008: 231) }\end{array}$ \\
\hline
\end{tabular}




\begin{tabular}{|c|c|c|}
\hline $\begin{array}{l}\text { system. Successful implementation of this model } \\
\text { is seen as one way in which China can 'leapfrog' } \\
\text { past environmental damage that is typically seen } \\
\text { as economies industrialize. }\end{array}$ & & \\
\hline $\begin{array}{l}\text { The circular economy refers to an industrial } \\
\text { economy that is restorative by intention. It aims } \\
\text { to enable effective flows of materials, energy, } \\
\text { labour and information so that natural and social } \\
\text { capital can be rebuilt. It seeks to reduce energy } \\
\text { use per unit of output and accelerate the shift to } \\
\text { renewable energy by design, treating everything } \\
\text { in the economy as a valuable resource. }\end{array}$ & $\begin{array}{ll}\text { - } & \text { Restorative } \\
\text { - } & \text { Flow of material, energy, } \\
& \text { labour and information } \\
\text { - } & \text { Reduce energy } \\
\text { - } & \text { Shift to renewable energy } \\
\text { - } & \text { Resource Value }\end{array}$ & (EMF 2013: 26) \\
\hline $\begin{array}{l}\text { CE is an alternative to a traditional linear } \\
\text { economy (make, use, dispose) in which we keep } \\
\text { resources in use for as long as possible, extract } \\
\text { the maximum value from them whilst in use, then } \\
\text { recover and regenerate products and materials at } \\
\text { the end of each service life. }\end{array}$ & $\begin{array}{ll}\text { - } & \text { Resources in use } \\
\text { - } & \text { Extract maximum value } \\
\text { - } & \text { Recover and Regenerate } \\
& \text { products and materials }\end{array}$ & $\begin{array}{l}\text { (The Waste and } \\
\text { Resources Action } \\
\text { Programme, 2011) }\end{array}$ \\
\hline $\begin{array}{l}\text { The circular economy is an economic model } \\
\text { wherein planning, resourcing, procurement, } \\
\text { production and reprocessing are designed and } \\
\text { managed, as both process and output, to } \\
\text { maximize ecosystem functioning and human } \\
\text { well-being. }\end{array}$ & $\begin{array}{ll}- & \text { Maximize ecosystem } \\
\text { - } & \text { Social dimensions of } \\
& \text { human well-being }\end{array}$ & $\begin{array}{l}\text { (Murray et al. 2015: } \\
\text { 25) }\end{array}$ \\
\hline
\end{tabular}

Table 1. Circular Economy Definitions and Emergent Themes

In general, the concept mainly stresses closed flows of materials and increased efficiency in the use of raw materials and energy (de Jesus et al. 2017). This research very much relates to Murray et al. (2015)'s definition where the notion of circular economy is thus closely connected to the environment as well as the social dimension of human well-being. As this paper seeks to show, from a sustainability perspective, the definition of circular economy crucially depends on the scope of interpretation of ecosystem functioning - whether this is interpreted narrowly or in the broader scope of planetary boundaries. 


\subsection{Circular economy, sustainability and environment}

In contrast to the neo-classical view of economics, circular economy acknowledges the fundamental importance of the environment, its functions as well as the interrelationship between environment and the economic system. Circular economy takes its insight from living systems and draws inspiration and example from the natural world for the design of products and processes (EMF 2013b; Ghisellini et al. 2016). The approach is based on the premise that in a world of finite resources and limited possibilities to absorb waste, the current and traditional linear economic model - extract, produce, use, discard - is simply and manifestly unsustainable.

In the face of challenges related to securing resources, volatile resource prices and growing costs related to waste disposal, circular economy has offered governments and corporations a very practical approach to addressing these challenges (EMF 2015b). In a practical way that has been largely lacking with other approaches, e.g. The Economics of Ecosystems and Biodiversity (TEEB 2012), it has shown how to not only mediate these daunting challenges but even draw opportunity out of adversity, e.g. by helping identify new market opportunities within the existing economic system and paradigm of growth (Young 2018).

The limitation of this approach is that the environment benefits primarily through the decrease in waste and demand on resources (Korhonen et al. 2018). Only more recently in the development of the concept has there been a broader acknowledgement of ecosystem goods and services and their importance in sustaining life and livelihoods. In 2015, "preserve and enhance natural capital" was included as the first of three principles in the Ellen MacArthur Foundation's outline of a circular economy (EMF 2015a). Despite this acknowledgement, the overwhelming focus of circular economy has remained on addressing resource efficiency and waste. Only indirectly has the focus been on securing ecosystems and ensuring our civilization remains within planetary boundaries.

This is shortsighted given the defining challenge of the $21^{\text {st }}$ century to bring human civilization within the limits of the Earth's planetary boundaries as the global human population is projected to grow to 9.5 billion inhabitants by 2050 (OECD 2012). The ecological footprint of humanity has already far outstripped the Earth's capacity to sustainably produce resources and absorb waste (WWF 2016). As a result, several global 
tipping points have already been reached and exceeded including climate change, loss of biodiversity and impacts on ecosystems, land-system change as well as altered biogeochemical cycles with regard to phosphorus and nitrogen (Steffen et al. 2015; Röckstrom et al. 2009). Two-thirds of global biological diversity has been lost in the last fifty years, with significant and growing impacts on lives and livelihoods (WWF 2016; MunichRe 2018).

Based on a bibliographic analysis, Geissdoerfer, et al. (2017) have proposed circular economy as a subset of the older concept of sustainable development. Though often vague, concepts of sustainable development with their emphasis on social, economic and environmental dimensions ("people, profit and planet") usually include broader social dimensions, emphasis on economic benefits and a more complex environmental perspective than those presented by circular economy.

\subsection{Criticism of circular economy in terms of sustainability}

Given the overarching challenges facing our civilisation, contribution of a circular economy to overall sustainability is crucial. In their review of literature on circular economy, Geissdoerfer et al. (2017) note three relationship types between the circular economy and sustainability: one where circular economy is a main solution or condition for a sustainable system; one where circular economy is beneficial to sustainability, but not conditional; and a third type where circular economy represents a trade-off, with costs and benefits that could lead to negative outcomes or that contribute only partially to sustainability. Among the latter group, Andersen (2007) describes potential benefits from a circular economy but also costs. Allwood (2014) raises a number of issues, including cases where energy and materials gained through circular approaches may in fact have a higher environmental impact, e.g. in terms of greenhouse gases, than ones gained through traditional, "linear" means. A more pragmatic approach may therefore be needed that gives greater priority to material efficiency over circularity.

Korhonen, et al. (2018) point out the circular economy is not and cannot be perfectly circular - according to the law of thermodynamics, some energy and resources are lost 
through circulation. What circular economy seeks to do is to minimize this loss to a level that can be sustained by nature. Like a number of other authors, including Murray et al. (2015), Korhonen et al. (2018) also note the broader context for the circular economy, including environmental and social, and call for a more integrated approach - one that is better grounded in a broader perspective of planetary boundaries and ecosystem goods and services. Their proposed expanded definition of circular economy integrates this broader perspective and includes the three dimensions of sustainability, i.e. economic, environmental and social. Korhonen et al. (2018) highlights that circular economy is an economy constructed from societal production-consumption systems that maximizes the service produced from the linear nature-society-nature material and energy throughput flow. This is done by using cyclical materials flows, renewable energy sources and cascading. Successful circular economy contributes to all the three dimensions of sustainable development. Circular economy limits the throughput flow to a level that nature tolerates and utilizes ecosystem cycles in economic cycles by respecting their natural reproduction rates.

\section{Research Methodology}

The intervention question for this study is to what extent the circular economy concept contributes to environmental (and by extension economic) sustainability? In particular, can a circular economy in the Slovak forest sector ensure the long-term conservation of forest habitats and related ecosystem goods and services in Slovakia?

The study takes an inductive approach (Saunders et al. 2012), using a case study to test the propositions of Korhonen et al. (2018) that circular economy must be placed within a broader context of environmental and social systems. According to Myers (2013), a case study approach is useful in the early stages of a new area of inquiry and can be used to test theory. It is also appropriate where the investigator has little control over the focus of investigation (Yin 2009). 


\subsection{Data collection}

The investigation is based on a review of literature on circular economy and sustainable development as well as the forest sector, forest conservation and related ecosystem goods and services. It also draws on secondary data regarding Slovak forests and development of the Slovak forest sector published by relevant Slovak authorities, including the Slovak Forest Research Centre and Ministry of Environment.

Based on the initial focused literature review, key themes and patterns emerged (Yin 2009), including principally the current state of Slovak forests and forest sector as well as potential opportunities and challenges related to development of a circular economy. These themes were further empirically investigated through a series of interviews with fifteen experts and practitioners in the forest sector, forest conservation and circular economy, both from within as well as outside of Slovakia (see Table 2). The interviews served to canvas the opinions of relevant experts and practitioners as well as to fill specific knowledge gaps highlighted in the literature.

\begin{tabular}{|c|c|c|c|c|}
\hline$\#$ & Interviewee ID & Title, Organisation & Topics & Date/location \\
\hline 1 & SIB & $\begin{array}{l}\text { Regional Lead on Forests, } \\
\text { WWF-DCP/Romania }\end{array}$ & $\begin{array}{l}\text { Development of forest } \\
\text { industry, forest } \\
\text { conservation }\end{array}$ & $\begin{array}{l}\text { 19 January } \\
\text { 2018, by skype }\end{array}$ \\
\hline 2 & HB & $\begin{array}{l}\text { Knowledge Manager, Forests } \\
\text { Practice, WWF-Int }\end{array}$ & $\begin{array}{l}\text { Circular Economy, } \\
\text { sustainable fibre }\end{array}$ & $\begin{array}{l}6 \text { February } \\
2018, \text { Wien }\end{array}$ \\
\hline 3 & PB & Founder, Landscape Finance Lab & $\begin{array}{l}\text { Landscape stewardship, } \\
\text { finance }\end{array}$ & $\begin{array}{l}2 \text { February } \\
2018, \text { Wien }\end{array}$ \\
\hline 4 & PG & $\begin{array}{l}\text { Future-proofing Forests, Food \& } \\
\text { Freshwater, formerly Natural } \\
\text { Resources Manager, Mondi plc }\end{array}$ & $\begin{array}{l}\text { Development of forest } \\
\text { sector, sustainable fibre }\end{array}$ & $\begin{array}{l}2 \text { February } \\
2018 \text {, by phone }\end{array}$ \\
\hline 5 & MJ & $\begin{array}{l}\text { Biodiversity Officer, WWF } \\
\text { Slovakia }\end{array}$ & $\begin{array}{l}\text { Slovak forests, conservation } \\
\text { issues }\end{array}$ & $\begin{array}{l}\text { 19 January } \\
\text { 2018, by skype }\end{array}$ \\
\hline 6 & $\mathrm{JK}$ & $\begin{array}{l}\text { Manager Sustainable Business \& } \\
\text { Markets, WWF-Germany }\end{array}$ & $\begin{array}{l}\text { Circular Economy and } \\
\text { sustainability, role of NGOs }\end{array}$ & $\begin{array}{l}6 \text { February } \\
2018 \text {, by skype }\end{array}$ \\
\hline 7 & RL & $\begin{array}{l}\text { Founder, Ecology \& Pioneering } \\
\mathrm{AB}\end{array}$ & $\begin{array}{l}\text { Circular Economy and } \\
\text { forest sector }\end{array}$ & $\begin{array}{l}\text { February } \\
2018 \text {, by skype }\end{array}$ \\
\hline 8 & $\mathrm{AM}$ & $\begin{array}{l}\text { Global Forest Practice Leader, } \\
\text { WWF-International }\end{array}$ & $\begin{array}{l}\text { Forest conservation, } \\
\text { development of forest } \\
\text { sector, sustainable fibre }\end{array}$ & $\begin{array}{l}26 \text { January } \\
2018 \text {, by skype }\end{array}$ \\
\hline 9 & RS & $\begin{array}{l}\text { Category Developer Wood, } \\
\text { IKEA Industry }\end{array}$ & $\begin{array}{l}\text { Slovak forest sector } \\
\text { development, securing } \\
\text { sustainable fibre }\end{array}$ & $\begin{array}{l}7 \text { February } \\
2018 \text {, by phone }\end{array}$ \\
\hline 10 & ES & Founder ProPark Foundation & Forest conservation & $\begin{array}{l}\text { 15 January } \\
2018 \text {, Brasov }\end{array}$ \\
\hline 11 & RT & $\begin{array}{l}\text { Global Director Forests, World } \\
\text { Resources Institute }\end{array}$ & $\begin{array}{l}\text { Development of forest } \\
\text { sector, sustainable fibre, } \\
\text { conservation }\end{array}$ & $\begin{array}{l}2 \text { February } \\
2018 \text {, by skype }\end{array}$ \\
\hline 12 & JY & Director, Global Forest Sector & Development for forest & 6 February \\
\hline
\end{tabular}




\begin{tabular}{|c|l|l|l|l|}
\hline & & Transformation, WWF-Int & $\begin{array}{l}\text { sector, sustainable fibre, } \\
\text { social context }\end{array}$ & 2018, by phone \\
\hline 13 & MH & $\begin{array}{l}\text { Coordinator, Environmental } \\
\text { Paper Network }\end{array}$ & $\begin{array}{l}\text { Circular Economy, paper \& } \\
\text { pulp, sustainable fibre }\end{array}$ & $\begin{array}{l}\text { 20 February } \\
2018, \text { by skype }\end{array}$ \\
\hline 14 & IV & $\begin{array}{l}\text { Founder of Institute for Circular } \\
\text { Economy (INCIEN) }\end{array}$ & $\begin{array}{l}\text { Circular economy, } \\
\text { application to Slovakia }\end{array}$ & $\begin{array}{l}\text { 23 February } \\
\text { 2018, Bratislava }\end{array}$ \\
\hline 15 & PP & $\begin{array}{l}\text { Slovak forestry expert and } \\
\text { consultant }\end{array}$ & $\begin{array}{l}\text { Slovak forest conservation, } \\
\text { development of forest } \\
\text { sector }\end{array}$ & $\begin{array}{l}\text { 01 March 2018, } \\
\text { by skype }\end{array}$ \\
\hline
\end{tabular}

Table 2. Interview Participants

\subsection{Interview process}

The interviews were semi-structured, based on a set of questions that were tailored to the experience and expertise of each interviewee. All interviews were conducted by the principal author in person or via skype or phone, and lasted between 30 and 60 minutes, with additional follow-up in some cases for clarification and further information. The questions as part of the interview agenda served as a point of departure and guide rather than a corset for the interviews, with additional questions posed by the researcher depending on the flow of conversation as well as remaining gaps in knowledge or opinion. For example, the interview with AM, who has experience working with FSC, went into greater dept on certification systems, including their relative strengths and weaknesses. In contrast, the interview with IM revolved around ongoing circular economy initiatives in Slovakia and neighboring countries. Notes from the interviews were transcribed into MS word format by the author. Statements or references included in the study as well as the final study were provided to interviewees for review. In some cases, the quotations were expanded or amended on the request of the interviewee. The interview protocol underwent the standard university process for ethical approval for data collection methods and mode of collection.

\subsection{Case study validity and data analysis}

Given the breadth of the area of inquiry and the paucity of existing literature, the study took an exploratory approach based on qualitative research that made it possible to generate a richness of data not possible with a quantitative approach (Saunders et al. 2012). The approach based on existing literature augmented by interviews with a variety of relevant experts provided a richness of data that would not have been available if only relying on or the other. Areas for further inquiry, including quantitative analysis to further test and support the analysis, are indicated in the conclusions. 


\section{The Slovak forestry sector as a case study for circular economy}

\subsection{Forests and the circular economy}

Trees and forests themselves serve as prominent symbols of a circular economy, where waste (e.g. deadwood and leaves) provide critical inputs for further life (e.g. nutrients for the soil and new plants and trees). In terms of circular economy, trees and forests present biological, i.e. renewable resources - the left side of the so-called "butterfly" diagram of the circular economy described by the Ellen MacArthur Foundation (EMF 2018).

Forest management traditionally has also followed a circular model, with sustainable harvesting based on renewable (mostly human) energy and waste either used or returned to the soil (Mabee 2011). Later development of industrial forestry systems also pioneered circular models of industrial ecology: for example, the symbiosis between sawmilling and pulp milling, where the sawdust waste from one process provides an input for another process.

\subsection{Slovak forests and their significance}

Forests cover $2,016,729$ ha or $41 \%$ of Slovak territory and are thus a prominent landscape element and resource base for the country (NFC 2017). They include temperate and alpine forests dominated by beech (Fagus sylvatica), covering 33.5\% of total forest area; spruce (Picea abies) (23.1\%); and oak (Quercus sp.) (10.6\%). The greatest part of Slovak forests is devoted to production (72.2\%), followed by protection (17.25\%) and finally special-purpose forests (10.5\%) where social and cultural functions prevail (NFC 2017). Approximately half of Slovak forest production is in state hands.

From a macroeconomic perspective, the forest sector - which includes both harvesting and processing - is a relatively insignificant part of the Slovak economy, which is driven largely by services $(64.8 \%)$ and industry $(31.6 \%)$, particularly automobile manufacturing (Theodora 2017). In 2016, the value of gross domestic product of the Slovak forest sector came to $€ 270$ million, or $0.33 \%$ of national GDP, and provided 10,600 jobs, i.e. $0.43 \%$ of the country's total employment (UNECE 2017). 
One reason for the forestry sector's poor economic performance is the fact that over a quarter of the country's total production of timber, i.e. 2.45 million $\mathrm{m}^{3}$ of a total of 9.32 million $\mathrm{m}^{3}$ in 2016 (NFC 2017), is exported without significant added value from domestic processing. Domestic capacity for production of the highest quality round wood is low $(0.3$ million $\mathrm{m}^{3}$ ) (NFC 2017). A relative exception is the pulp and papermaking sectors, which are among the best performing industries in the national economy. According to The WWF Regional Lead on Forests, Slovak forests yield much more than timber:

"Complex forest ecosystems provide a lot of important ecosystem goods and services, many of which are important to the lives and livelihoods of people. Services include water management, clean air, local climate regulation, carbon sequestration, biodiversity, recreation, and much more. Non-timber forest products such as mushrooms and berries are important non-timber forest products in Central and Eastern Europe." (SIB)

As the statement above highlights, collecting mushrooms in Slovak forests implies revenues of €110-140 million annually though picked mostly for own consumption, (Kovalčík 2014), i.e. almost a third of the forest sector's contribution to the national economy. Virtually all forest lands also serve hunting, which in 2016 brought total earnings of $€ 14,546,000$ (NFC 2017). Tourism - which in 2016 contributed an estimated $€ 1.9$ billion to the Slovak economy (2.4\% of GDP) and generated 150,000 jobs (WTTC 2017) - is also significant, considering that the key attraction of the country for Slovaks and foreigners alike is its natural heritage, mostly associated with forests.

Less tangible is the role of Slovak forests in supporting biodiversity. Biomass is critical for the biological diversity of forests, not only in terms of living but also deadwood, on which up to a third of European forest species depend for their survival (Dudley and Vallauri 2004; Bobiec et al. 2005). Slovak forests are also critical for water and flood management, an issue of growing concern in the light of climate change (Ministry of Environment 2014). Between 2002 and 2013, 24 floods caused an estimated $€ 790$ million in total direct costs, not to mention dozens of fatalities (Zeleňáková and Vranayová 2014). As sinks for half of the Earth's carbon, forests also have a critical role to play in addressing climate change (Bonan 2008; Keith et al. 2009). They are also important for climate change adaptation, e.g. through the role that they play in local climate regulation as well as in strengthening resilience to climate change (McCarthy et al. 2001). 
Pinning an economic value on many of these services is an inexact science at best. What is clear is that Slovak forests - as all forests - provide far more tangible as well as intangible benefits than "just" wood, and these benefits need to be taken into account in determining the future of these ecosystems.

\subsection{Slovak forests the focus of conflict and competition}

There is a deep conflict at present over the future of Slovakia's forest resources. The interviewee from the IKEA industry group highlights that domestic processors complain of the large volume of high-quality raw timber that is exported without providing added value to the Slovak economy. According to the interviewee:

"A significant portion of Slovak pulpwood production is exported via trading companies to Romania, the Czech Republic and other countries, traveling significant distances and taking supply away from domestic needs. From a macroeconomic and ecological perspective, this does not make sense." (RS)

Apart from the large amount of timber being exported, there is also competition over lowgrade timber between paper and pulp as well as bio-energy, with the latter accused of unfairly benefiting from EU subsidies for green energy. There is also a deep gulf between foresters and conservationists. The latter are concerned about the state of the country's most valuable forest habitats. Approximately $60 \%$ of forest habitats of European interest, i.e. those that are the focus of EU nature conservation legislation, are considered to have unfavorable conservation status (Slovak Ministry of Environment 2010). Declining populations of capercaillies (Tetrao urogallus, or wood grouse), which are good indicators of forest management, underline this concern (Mikoláš, et al. 2017). A prominent public awareness campaign "My jsme les" ("We are the Forest") launched in 2017 with support from a number of celebrities criticizes excessive felling, particularly of Old Growth Forests (My jsme les 2018). Slovak timber harvesting has doubled over the past decade, largely due to incidental fellings that are the result of wind throws (NFC 2017). According to Slovak forest expert PP, maintaining such a rate is unsustainable (Polak 2018).

A major focus of conflict between conservationists and foresters is the treatment of protected forest areas afflicted by bark beetles and wind throws (Kapitán 2017). Foresters say that the affected wood must be removed in order to prevent the epidemic from spreading 
to other areas. Conservationists have claimed such arguments are merely a profit-seeking excuse to remove timber from protected areas. They see bark beetle epidemics as a part of natural dynamics that in protected areas should be allowed to run their course. As per the interviewee from IKEA, these problems are set to only worsen in future:

"A major problem is climate change, which is leading to increasing average temperatures, decreasing average precipitation as well as more extreme weather, which is impacting timber harvests, especially for conifer monocultures planted in the previous century." (RS)

The situation is not helped by the fact that the relevant Slovak legislation regulating protection on the one hand and forestry on the other is unclear and even contradictory. The Biodiversity officer at WWF Slovakia highlights that:

"Large areas of the country enjoy some form of protection - but this is largely on paper rather than in actual practice. In fact, in most areas there is little real protection - there are cases of Old Growth Forests in core zones of national parks being logged, and this completely legally." (MJ)

At the same time, IKEA's expert (RS) points out, the protected area restrictions lead to uncertainty and additional administrative costs for foresters. In short, Slovak forests and fibre are already the focus of considerable conflict and competition. In the next sections we will see how a circular economy could help address these challenges.

\section{Opportunities for a circular economy for the Slovak forest industry and forests}

A shift to a circular economy presents significant and even exciting opportunities for the Slovak forest sector, with considerable economic and social benefits for the country. Wood fibre has the potential to play a central role in the circular economy. Given its significant forest resources, relatively central geographic location, well-educated labor force as well as existing capacity in paper and pulp manufacture, Slovakia has key factors in place to take advantage of this development. The Regional Lead on Forests at WWF-DCP Romania clearly stresses the importance of circular economy in the forestry sector by stating:

"We need to better use the resources we have - to promote long life-cycle products. We need to create products where we can re-capture and re-use and re-cycle the material. There are also new opportunities for using wood, e.g. as replacement for concrete." (SIB) 
It is no doubt that wood has a number of qualities that make it especially appealing from a circular economy perspective (WWF 2012). Wood is renewable, recyclable and biodegradable, and sequesters carbon from the atmosphere. Engineered and synthesized by nature, wood can be produced with less energy than many materials. It is also durable, relatively light and easier to handle than other materials, as well as aesthetically pleasing.

In a circular approach, fibres are used, re-used and recycled in an optimal way, with the highest possible value added at each stage and with the end product turned into energy or fertilizer (EMF 2013a). The focus is on optimizing the efficiency of resource use by on the one hand designing out waste, lengthening cycles and cascading resource use; and on the other shifting from non-renewable energy and materials to renewable sources. On all accounts, innovations are significantly expanding opportunities for drawing much more benefit out of wood resources.

\subsection{Increasing efficiency of use of wood fibre}

One opportunity for making better use of wood is to extend its use. Innovations in chemical and thermal treatment as well as nanotechnology can enhance mechanical properties as well as durability, including resistance to traditional banes such as fungi and moisture, significantly extending the life and usefulness of wood, paper and packaging (Espinoza and Laguarda-Mallo 2016).

Another key to unlocking significant potential is through capturing and re-using the resource, with use cascaded from higher- to lower-level uses, e.g. from buildings, then furniture, then packaging and finally energy or fertilizer to replenish soil (EMF 2013a). Currently wood for each of these uses is typically sourced directly - a tree is cut down to produce lumber for home construction, and then sent to landfill at end of use; a tree is cut down to produce wood for furniture or paper, and then likewise sent to landfill at end of life (Mabee 2011). According to a Slovak forestry expert and consultant, Slovakia has a long way to go in this respect and states that:

"Wood is very poorly used in Slovakia, with limited added value. Most wood is used for production of panels, paper and packaging, and biomass for energy." (PP) 
Industry is currently not organized to reclaim and re-use fibre, with the exception of the paper and packaging industry, where recycling back to paper has become the norm thanks to policy. Contamination e.g. through past application of preservatives, paints or glue, is another problem (Vis et al. 2016).

Overcoming these barriers will require considerable efforts, eased by technology and innovation. But they could lead to significant savings in terms of cost and resources. Analysis by McKinsey (EMF 2015a) suggests the potential for savings of up to $€ 9,600$ per household annually from circular buildings. Buildings could become material banks designed in such a way that parts can be easily removed and replaced to meet the needs of its users and to facilitate recovery, reuse and recycling of parts (EPEA Nederland and SundaHus 2017). Improving design of paper and cardboard, which already enjoy relatively high collection rates, to reduce quality loss and ink contamination that hinder re-use could save the EU as much as $\$ 32$ billion annually (EMF 2014).

In material terms, the greatest potential for cascaded use of wood lies in utilizing the waste from production processes (Vis et al. 2016). Developments in technology are improving the efficiency of sawmills, which in Europe operate on average at ca $70 \%$ efficiency, i.e. $70 \%$ of sawn logs are converted to sawn lumber (Enters 2001). At the same time, innovations in product design are finding new uses for byproducts of production of timber such as sawdust and waste wood. As one of WWF's expert (ISB) points out, development of veneers, for example, makes it possible to produce boards and structural elements with only a fraction of solid wood previously needed (Banciu 2018).

A major use of timber in Slovakia, and worldwide, is for producing paper and pulp. Traditional pulp making uses about 50\% of any given tree harvested, with the left-overs chiefly lignin and hemicellulose - burned for energy (Ramage et al. 2017). But - as the next section discusses - innovations are finding new, higher-value uses for lignin and hemicellulose beyond energy. As a result, there are now opportunities to develop an industrial ecology around the manufacture of paper and pulp, with the addition of small chemical plants to capture and process the waste - or "side streams" as people in the industry prefer to put it. The result is an increasingly circular process with significantly improved efficiency of resource use and minimization if not elimination of waste. 
Perhaps most exciting are the new opportunities that are opening for renewable wood fibre to substitute for a wide range of non-renewable and often carbon-intensive resources in a wide array of applications, from construction to household products.

As a renewable resource, timber is the only widely used building material that can truly be sustainable (Ramage at al. 2017). There is considerable scope for expanding use of wood as a structural element, replacing non-renewable and heavier materials such as concrete and steel. Engineered wood products like Cross-Laminated Timber not only store carbon, but have lower environmental impacts during their manufacturing and disposal and in many respects exhibit superior qualities to traditional materials (Espinoza and Laguarda-Mallo 2016; Extension 2015). Wood is particularly attractive where strength- or stiffness-to-weight ratio is more important than absolute strength or weight - e.g. where the construction element must carry its own weight, as on roofs or in high buildings such as skyscrapers (Ramage et al. 2017).

Technological advances are enabling new uses of wood and its chemical components (Poyry 2012). Bio-plastics and bio-composites are being developed that can replace oil-based materials like plastic or fiberglass for manufacture of everything from coffee pots to computers, printers and automobiles. Development of nanotechnology is opening new vistas in the use of wood fibre. Microscopic fibrils from cellulose can be manipulated to enhance properties, e.g. aligning them for strength or more randomly for flexibility, for use in a wide range of applications from strong structural elements to soft textiles (Larsson 2014). The transparent, gel-like material made from the fibrils can be used in paper to enhance properties, e.g. strength or as a barrier for grease or liquids, or added to baking products, e.g. bread and muffins, to add fluffiness and retain moisture (Lavoine et al. 2012). Nanocellulose can also serve as a low calorie replacement for carbohydrate additives in thickeners, flavour carriers and suspension stabilizers in food products. It also can be used in hygiene, as a super-absorbent material (e.g. for diapers), or in textiles, in carpets, fibres, fabrics, Lycra or spandex (Lavoine et al. 2012). Nanocrystalline cellulose (NCC) can be used in electronic displays, lightweight body armor or computer components (Ferguson 2012). 
Renewable biomass also has the potential to replace at least some of our dependence on nonrenewable and polluting fossil fuels. From a circular economy perspective, the substitution of renewable for non-renewable energy forms is appealing, but it needs to be balanced with other considerations (EMFa 2013). Gaining biofuels, for harvesting, transportation and processing, also requires energy, and this has to be taken into account in order to ensure there is a net benefit in terms of energy. Care also has to be taken that the demand for biomass for energy does not lead to unsustainable forest management or take wood from higher-level uses (Carus 2017). In Slovakia, volumes of biomass used for energy have tripled since 2000, putting significant pressure on forest biodiversity and resources (Vlk 2013). For these reasons, WWF and other conservation organizations are ambivalent toward biomass for energy (Leithe 2018). "We need to be careful about using biomass for energy, limiting it to the use of waste", says AM, Global Forest Practice Leader for WWF (Monument 2018).

\subsection{The new business of stewardship and regeneration}

Our consideration has so far focused on the use of wood fibre. Another opportunity relates to maintaining and restoring ecosystem goods and services (EMF 2013b). A glance at the range and value of ecosystem services provided by Slovak forests highlights the opportunity for Slovak foresters to play a much broader role as stewards of the forests. According to one of the founders of a forestry foundation called Propark:

"Forests are much more than just the wood of the trees that grow in them, so there is a real opportunity for foresters to do much more than cut down and plant trees for commercial logging. We need them to care for the many ecosystem services on which we depend. This is a role that foresters have traditionally ascribed to themselves, but that at least in recent years has diminished in favour of extracting wood." (ES)

Increasing appreciation by society of ecosystem goods services should translate into a strengthened business case, with sustainable wood harvesting augmented by income from mushrooms, berries and other non-timber forest products, tourism and recreation services, private investments in carbon sequestration as well as public subsidies for conservation measures or watershed protection. 


\section{Challenges of circular economy for the Slovak forest industry and forests}

Despite these opportunities, challenges remain. An expert from the the Environmental Paper Network underlines the trade-offs and opportunity costs involved in deciding between options:

"We need to ask some deep questions - whether we invest $€ 2$ billion for a new paper and pulp mill with waste capture or invest that money in recycling of paper, where it could have a really transformational effect." (MH).

Wood is a renewable resource, but also a finite one - and it is not certain how much fibre the circular economy will eventually need, i.e. what the balance will be between increasing efficiency of use versus increased demand from new applications. Given the projected increase in global population, even with greater efficiency, net demand for wood fibre is likely to grow (WWF 2012). Recent projections see a significant increase in demand for wood - e.g. the EU financed EUWood study assumes a $40 \%$ growth in volume demand by wood using sectors by 2030, with strong demand particularly in the building sector replacing steel and cement (Mantau et al. 2010). At the same time, demand is growing for biomass for energy (European Commission 2011). MJ fears the impact that an increase in demand could have for Slovak forests:

"Increased demand for wood will either lead to further felling, including Old Growth, protected and other valuable forests, or to reductions in cycles of forest felling for example of pine from the current 110 to 80 or 60 years - this would significantly reduce the complexity of forest ecosystems and associated benefits." (MJ).

Plantations could help meet an increased demand for fibre (WWF 2011). IKEA's Robert Slaninka (2018) says that in Slovakia the company has already created 500 hectares of fastgrowing poplar plantations, which it expects could supply as much as a third of the biomass for its plant at Malacky. Plantations could present an attractive option not only in Slovakia but also across wider areas of Central and Eastern Europe, where changes in land use are leading to the abandonment of agricultural land (Alcantara et al. 2013). WWF's global forest leader Alistair Monument says that making more intensive use of such marginal areas could make sense if they do not replace high nature values such as rare meadow ecosystems, and if they are cultivated in an environmentally-friendly manner, e.g. according to New Generation Plantations principles (Monument 2018). Such standards are important not only for preserving biodiversity, but for ensuring the resilience of the plantations themselves and 
avoiding the growing problems associated with intensive agriculture, such as depleted and poisoned soils and polluted water.

Nevertheless, there is a very real threat that an absolute increase in demand for biomass will crowd out other uses, including essential ecosystem goods and services, at a time when these are already under considerable pressure. A shift to a circular economy could close the loop on biomass, but crowd out other uses, effectively undermining efforts to achieve long-term sustainability. Clearly, efforts to shift to a circular economy in the forest industry need to take into account a broader context, including competing needs for biomass (O'Brien 2017). Even with circular approaches, resource availability will remain a key challenge.

\section{Ensuring sustainable sourcing}

Ensuring the efficient use of wood fibre is only part of the equation. Ensuring sustainable sourcing of fibre is also needed.

\subsection{Voluntary measures: Certification}

In the absence of adequate regulation of sustainable forest harvesting, forest purchasing companies need a credible system that can ensure them - and their customers - that they are purchasing sustainably sourced timber. Forest harvesters in turn need to be able to prove to purchasers that the timber they sell comes from sustainably managed stands. Certification systems have been developed to meet these needs, providing independent, third-party verification for both forest management and chain-of-custody sourcing (Gulbrandsen 2004). The two leading certification systems worldwide are FSC and PEFC (FSC 2018; PEFC 2018). Many industry leaders, including Mondi, IKEA and Kronospan, have signed up to one or the other, or both, of the certification systems (Mondi 2017; IKEA 2018; Kronospan 2018). In Slovakia, PEFC dominates, with $1,229,000$ ha or $64.1 \%$ of the total forest area certified according to the PEFC standards (NFC 2017). FSC is anemic in comparison, with 146,271 ha designated in Slovakia according to the FSC standards (NFC 2017), but there are recent attempts - driven by demand for FSC timber - to develop a national standard and promote the scheme in the country (Janák 2018). 
Critics have charged that the forest certification schemes have weak standards and essentially greenwash unsustainable forest operations (FSC-Watch 2018). Studies indicate that certification has made a difference (Burivaloval et al. 2017; Moore et al. 2012), particularly in countries like those in Central and Eastern Europe with weak governance and enforcement (Banciu 2018; Cashore et al. 2006). Alistair Monument, who used to work for FSC and now leads WWF's global forest work, does not deny individual problems with certification, but emphasizes these can and should be addressed through the certification system. In this respect, FSC is more credible than PEFC as it is based on a three-chamber system that includes social, environment and industry in governance (Walter 2008; Greenpeace 2014; WWF 2015).

There is an extensive literature on both the advantages but also limitations of voluntary efforts by the private sector to raise environmental standards (e.g. Gunningham and Sinclair 2002; Lyon 2013). A key vulnerability of industry efforts to promote sustainability is the dynamics of the industry. Economies of scale are a key factor driving e.g. development of the paper and pulp industry, with investments in technology and mechanization limiting labour inputs and driving down unit costs. These both undermine efforts at industry-wide cooperation as companies race forward to grab advantage of increased scale, and also undermine efforts at sustainable resource use given ever-increasing demand for biomass.

A circular approach questions whether this business model is appropriate. As the expert from Environmental Paper Network puts it:

"The future of the European paper industry is in value and not volume. Half of the end products of the paper and packaging industry are currently viewed by customers as trash! The industry should re-think what they do, focusing on increasing value and decreasing volume" (MH).

\subsection{Regulation and the "Rules of the Game"}

Industry should have a shared interest in a level playing field, with clear rules of the game that can ensure long-term sustainability of their supply chain as well as other needs. WWFDCP lead (SB) for forests, notes that government and relevant authorities have an important role to play not only in regulating harvesting as well as securing key ecosystem goods and 
services provided by forests (Banciu 2018). They are also best placed to shape - through regulation, subsidy and sanction - the conditions for the balanced use of forest ecosystems, e.g. providing tax credits for FSC certification and purchases; supporting measures to preserve high conservation values; or penalizing unsustainable practices. Government can help integrate ecosystem services in forest management by fostering private markets giving a value to forest ecosystems, e.g. by paying forest owners for the public goods and benefits they provide, such as water management, biodiversity and climate regulation; or encouraging protection schemes supported through carbon offsets (Patterson and Coelho 2009).

Unfortunately, governance in Slovakia is relatively weak and government fills these roles imperfectly at best.A Slovak forestry expert (PP), says that there is an urgent need to improve the legislative framework - to improve protection for the most valuable areas, possibly in return for a decrease in area under protection as broached in the past; and to better control logging (Polak 2018). Domestic processing of wood, which could generate added value in terms of income and jobs for the national economy, is hampered by a shortage of supply of wood while high-quality raw timber is exported.

What is needed is a more holistic approach to the management of forest as well as other natural resources, to address current and future conflicts and secure a sustainable future. Indeed, current conflicts over fibre may just be a warm-up for the future. While the focus now is on biomass - for production or protection - the bigger issue in the future will be over land.

\subsection{The need for a holistic approach}

The challenge is to mediate the allocation not only of fibre, but of the land on which it is produced - land which can be used for producing fibre or food or for other uses (Brandlmeier 2018). Competition for use of land will increase in future as the global population grows from 7 to 9.1 billion people by 2050 and global agricultural output increases by $70 \%$ (FAO 2009). Against this backdrop, the present approach - managing different parts of the resource base like forests and rivers rather independently in pursuit of different sectoral goals, e.g. fibre or crop production, watershed protection or biodiversity 
conservation - is inadequate. Different land uses depend on the same resource base, and improving output for one sector can have negative impacts on other sectors as well as the overall availability of resources.

A holistic approach to managing the resource base is needed. The founder of the Landscape Finance Lab (PC), recommends the landscape approach, which is being applied in a growing number of places around the world, as a way to bring competing interests together for collaborative planning that delivers multiple functions for the different stakeholders (Chatterton 2018). The approach has five steps, including establishing a multi-stakeholder platform; ensuring that the stakeholders have a shared understanding of spatial relationships and their respective roles in the landscape; collaborative planning; effective implementation; and monitoring and learning (Denier et al. 2015).

There are potentially important catalysts that can encourage such a holistic approach in Slovakia. EU legislation, which provides a framework for domestic regulation, requires an integrated approach to resource management, e.g. through the basin-wide planning mandated by the EU Water Framework Directive or regional planning required for programming for EU regional development programmes. Such planning does take place on paper, but it is only poorly reflected in actual practice - e.g. the sub-river basin management plans required by the EU Water Framework Directive are coherent, but disconnected from the measures for actually implementing these plans. There are also numerous potentially relevant policy frameworks and initiatives, including the EU Action Plan for the Circular Economy (European Commission 2015) and the UNECE Rovaniemi Action Plan for the Forest Sector in a Green Economy (UNECE 2014).

Nevertheless, among relevant stakeholders, including government, forest and other sectors as well as civil society, there is insufficient understanding, awareness and recognition of the different uses of the landscape, the perspectives of different stakeholders and the spatial relationships between them. Many stakeholders from government and the forestry sector do not seem to understand and appreciate the broader environmental context. A forester and conservationist from ProPark who comes with extensive experience working in Slovakia and other countries of the region states that "The forest industry is conservative - one of the key challenges is getting foresters to open up and consider other sectors and needs, " (Stanciu 2018). Similarly, conservationists may not fully appreciate the socio-economic context. 
Without an appreciation of the broader context and each other's perspectives, there is no basis for mutual understanding, let alone collaborative planning and implementation despite ultimately a common interest in securing the long-term economic, environmental and social sustainability of the Slovak forest sector and forests.

In short, what is needed is good governance - a form of democratic decision-making that can appreciate and take into account different perspectives and ensure collaborative planning, implementation, monitoring and learning. That decision-making needs to take into account a global dimension, including the interests of distant people, says the Knowledge Manager (HB) for the WWF global forest practice:

"When it comes to decision-making on resource use and allocation, it is important to keep in mind issues of global fairness - we all need to be more efficient in our resource use, but in wealthy regions of the world this may also mean reduction of resource use, while in others it means sustainable growth." (HB)

Her point underlines the broader social context in which the circular economy must be placed, and which is generally missing in current approaches to the concept (Korhonen et al. 2018; Murray et al. 2015).

\section{Bringing the circular economy to the Slovak forest sector}

The preceding discussion suggests that the time is ripe for change in the Slovak forest sector, and circular economy can present an attractive solution. The challenges facing the Slovak forest sector are legion. There is a growing problem with sourcing wood, while at the same time the resource is relatively poorly used, with only limited generation of jobs and contribution to the national economy. At the same time, the condition of Slovak forests is deteriorating, with decreasing biodiversity and economic value. Forest management and conservation is the focus of significant conflicts, both within the sector and with conservation and significant parts of the general public. Moreover, there does not appear to be any solution to these problems in sight.

Against this rather bleak backdrop, circular economy holds the promise of a positive vision for the Slovak forest sector and the country's forest ecosystems - one that promises significant development for the industry and can provide a bridge to a vision for sustainable 
ecosystems. That vision is already coming into focus in Finland, where the government sees the forest sector playing a key role in a circular economy with a potential added value of $€ 1.5-2.5$ billion (Sitra 2016a) and at least 75,000 additional jobs (Wijkmann and Skanberg 2015). The Finnish government has identified the pulp and paper industry as one of five priorities, delivering a potential added value of $€ 220-240$ million per year (Sitra 2016a)

Although we are missing the same quantitative analysis for the Slovak case as has been done for Finland, there is no reason to think that circular economy approaches could not yield significant benefits also in Slovakia. This would significantly help the sector, given the currently relatively low level of value added to the economy, investment and employment. The prospect is all the more interesting given the fact that they would accrue especially to rural areas with the greatest need for economic and social development, with significantly more added value, including more professional and qualified employment.

There could also be significant other benefits. A more circular approach involving cascaded use of wood could lead to significant additional sequestration of carbon, helping the country reach its global commitments toward curbing greenhouse gases (Skog and Nicholson 1998). It would also reduce landfill and reduce dependence on fossil fuels. Related issues of air and water pollution could be addressed through improved technology and processes (OECD 2010).

For the Slovak forest sector, a circular economy promises significant opportunities for savings through greater efficiencies and especially for greater revenue both from existing as well as new products and applications. Processing companies can march up the value chain by producing new forms of engineered products. Paper and pulp making companies can use their ability to process large amounts of biomass and break it down into its chemical components in order to become a new kind of chemical companies. There will be opportunities also for smaller players to fill existing and create new niches in the developing ecosystem of production based on the expanded uses of biomass, e.g. producing specialty plastics, components and other products, or providing analytical and consulting services. Alliances with companies from other sectors, from chemicals to construction, electronics and consumer goods, can help forest companies unlock and realise the potential of wood. 
Of critical importance in developing toward this future is that other ecosystem goods and services provided by forests are both taken into account and safeguarded. Mediating this challenge can open further opportunities for the forest sector, particularly if there are more financial incentives to safeguard other forest use, from recreation to biodiversity and climate regulation. By balancing wood extraction and emphasizing other forest uses, foresters in Slovakia can position themselves as stewards of the forests, and draw new income streams from public subsidies, tourism and recreation as well as premiums on the price of sustainably sourced wood.

The Slovak government has taken some initial steps toward exploring the potential of a circular economy, particularly related to waste (Males 2018) and automobile manufacturing (UNIDO 2017). However of the Founder of the Slovak Institute for Circular Economy (IM) notes that the country is far from having the determined and well-coordinated approach to circular economy development that is being driven forward in other countries (Males 2018). What is lacking first and foremost in Slovakia is a greater understanding and appreciation of the country's natural resources and a coherent vision for the future.

\section{Lessons Learnt and Recommendations}

The research findings suggest that the Circular Economy, when narrowly interpreted, can complement but not replace efforts to achieve sustainability within planetary boundaries. The findings imply important actions for all societal actors to take to ensure that the circular economy is in fact truly sustainable.

In line with Desing, et al. (2020) political decision-makers have a particularly important role to play in creating a supportive framework of regulations and incentives. Through a mixture of convening relevant stakeholders, regulation, taxation and support, governments and relevant authorities can create the "rules of the game" for societal actors not only to take into account but also actively promote sustainability. Such actions can be guided by sustainability frameworks such as the One Planet Living approach developed by Bioregional (Bioregional 2020). 
Private companies need to ensure that in driving to develop "circular" products or processes they take into account broader sustainability indicators, e.g. related to biodiversity or climate change. A range of different tools and approaches already exist for doing this, including the science-based targets that many companies are using to gauge and address their greenhouse gas emissions (Science Based Targets 2020) or impacts on biodiversity (Science Based Targets Network 2020). Swedish outdoor company Houdini has blazed a trail with the publication of the first ever corporate sustainability report based on the holistic Planetary Boundaries framework (Houdini 2018).

The scientific community in turn must provide the monitoring and evaluation to guide these efforts, while educators must ensure that current and future generations have a broader awareness and understanding of planetary boundaries, ecosystems and system dynamics as well as the skills for identifying and developing solutions. The non-profit sector (particularly environmental organisations) also has a vital role to play in supporting development of a circular economy. They can work with public and private sector partners to promote the concept as well as provide practical support for example for sustainable sourcing or the cascaded use of wood. However, their most important role is to make the link to broader environmental and social issues. As the circular economy lead for WWF-Germany (JK), puts it:

"We need to contextualize the shift to a circular economy - to help governments, companies and other actors to make the connection between the circular economy and the broader context, from biodiversity loss to greenhouse gas emissions." (JK)

In this light, the WWF's Director of Global Forest Transformation (JY), sees a role in encouraging and supporting development of the forest sector:

"The forest sector is relatively conservative. It needs coaxing into realizing that they can seize a role in pioneering sustainability. They can tackle degradation, support biodiversity and other ecosystem services. We need to continue collaborating and pushing them to be more confident and enabled to fulfill the potential we see." (JY)

A retired Natural Resources Manager for Mondi (PM), the global paper and packaging giant, says the forest sector has a strong environmental record, especially compared with agriculture. However, he agrees that the forest sector needs encouragement to demonstrate that at landscape level it can further improve on protecting biodiversity and other ecosystem 
services whilst maintaining or enhancing commercial wood fiber yields, i.e. more resilient landscapes for forest products and services.

Landscapes -- "a socio-ecological system that consists of natural and/or human-modified ecosystems, and which is influenced by distinct ecological, historical, economic and sociocultural processes and activities" -- may present an appropriate scope for assessing and addressing impacts and measures (Denier, et al 2015). Such areas, which can be as distinct as the Zahorie area bounded by the March/Morava River and Small Carpathian mountains in Western Slovakia or extend to a larger area such as the large part of Slovakia dominated by the Carpathian Mountains, reflect not only socio- and ecological systems but also interrelated economic and political-administrative systems as well. They thus present a natural focus for the kind of integrated approaches required for a local circular economy respecting the local ecosystems on which it depends.

The following is a list of recommendations (by no means exhaustive) for cross-sectoral partnership between the public, private and non-profit sectors to seize opportunities and address challenges related to a circular economy in the Slovak forest sector.

- Promote the circular economy in Slovakia. In doing so, highlight the opportunities related to the concept, but also the need to place this in a broader environmental and social context.

- $\quad$ Follow the example of Finland and Slovenia, among others, in developing a national dialogue on a Circular Economy for the Slovak forest sector. Bring together key stakeholders from the private, public and non-profit sectors in developing a positive vision for Slovak forests and the forest sector, one that includes different needs and takes into account both demand and supply of biomass and other relevant materials.

- Within this framework, clarify and improve legislation and regulation as well as policies to promote a Circular Economy and broader sustainability, e.g. related to improved regulation of harvesting and protection or improved conditions for recycling of materials.

- $\quad$ Explore the development of financial support and incentives to promote Circular Economy approaches in the Slovak forest sector, e.g. green bonds or private investment facility. 
- Eventally, expand dialogue to a broader discussion and consideration of the use of land and resources.

- Promote sustainable management of Slovak forests, e.g. according to FSC standards, as well as conservation for all Virgin and Old Growth Forests. Support identification and protection of High Conservation Value Forests in FSC and other certification schemes.

- Support consumer awareness and acceptance of circular economy approaches, including e.g. non-toxic dyes. Promote the cascading use of wood from high to lower value uses, e.g. by advocating reform of the EU Renewable Energy Directive, which is driving the harvesting of biomass, including high-quality timber, for pellet production.

- $\quad$ Promote education and awareness regarding systems and planetary boundaries as well as relevant skills, e.g. designing and developing non-toxic and biodegradable packaging. Develop entrepreneur and business incubation programmes focused on a circular economy for the forest sector, related to wood re-use and recycling.

In sum, if a circular economy is to be achievable in any sector, all stakeholders (governments, organizations/businesses, policy makers, NGOs, consumers/users) need to work together and innovate by challenging current thinking and approaches towards a common goal of attaining economic, social and environmental value. This supports the view of Desing, et al. (2020) that a paradigm shift is needed for a transition towards a sustainable resource-based circular economy - a shift in the way environmental considerations are perceived by individuals, codified in different normative frameworks and dealt with by private companies.

\section{Conclusions and Future Research}

The case for a circular economy is compelling, with significant benefits in terms of economic development, employment as well as environment - a clear improvement over the linear take-make-use-and-discard approach. Considering the existential threat facing our civilisation, increasing the efficiency of our resource use is important, but insufficient. The 
circular economy must be "regenerative and restorative by intention and design" (EMFa 2013), for our ecosystems and our society - and this cannot be a footnote or an afterthought. Indeed, as this study finds, given the shrinking bio-capacity that we have available, we need to consider using actually less resources - a challenge for a circular economy approach that is more of an "alternative growth discourse" than an "alternative to growth discourse" (Charonis 2012).

Given the breadth of the topic and limited literature available, this study has focused on scoping issues relevant to a circular economy in the Slovak forest sector. Follow-up investigations could provide quantitative analysis of impacts in terms of economic value and jobs like that already done for Finland (Sitra 2016) as well as environmental and social parameters, such as carbon stock, emissions and biodiversity. Further investigations of circular economy approaches, including cases studies, are needed in Slovakia and other countries in Central and Eastern Europe. More generally, further investigation is needed into the actual impacts of circular economy in terms of broader issues of sustainability, including how such initiatives perform for example against the triple bottom line (Elkington 1997) or One Planet Business criteria (Elkington and Beloe 2007). A critical research gap identified by Winans et al. (2017) and underscored by this study is how land use can be integrated into circular economy-related initiatives, design and evaluation.

This case study of the Slovak forest sector supports Korhonen et al. (2018) in suggesting that the circular economy must be placed in a broader context, one that integrates environmental, social and economic systems. In doing so, it also supports the view of Geissdoerfer, et al. (2017) of circular economy as a sub-set of broader sustainable development. Fundamental to the concept of circular economy is the idea of a closed system. But what can be overlooked in this view are the broader systems in which such a system - however closed and circular - rests. A narrow circular economy focus can see the forest sector as perfectly circular, given the biological renewable resource involved but it may not be sustainable. Harvesting and growth may be balanced, but nevertheless crowd out other uses of resources, leaving too little biomass for other needs such as restoring soil or feeding biodiversity. In fact, competition for fibre has to be placed within a wider competition for land, and decision-making on these issues takes place within the constraints not only of broader environmental systems, but also of social and cultural systems that ultimately shape how we make those decisions. 


\section{Acknowledgement}

The authors would like to thank WWF (World Wide Fund for Nature) and all the interview participants from the various organizations for their valuable time, support as well as followup discussions and correspondences to help with this research. 


\section{References}

Alcantara, C., Kuemmerle, T., Baumann, M., Bragina, E., Griffiths, P., Hostert, P., Knorn, J., Muller, D., Prishchepov, A., Schierhorn, F., Sieber and A., Radeloff, V. (2013), "Mapping the extent of abandoned farmland in Central and Eastern Europe using MODIS time series satellite data", Environmental Research Letters, Vol. 8, No. 035035.

Allwood, J. (2014), "Squaring the circular economy: the role of recycling within a hierarchy of material management strategies", in Worrell, E., Reuter, M. (Eds.), Handbook of Recycling: State-ofthe-art for Practitioners, Analysts, and Scientists. Elsevier, New York, NY, pp. 445-477.

Andersen, M. (2007) An introductory note on the environmental economics of the circular economy. Sustainability Science, Vol. 2, No. 1, pp. 133-140.

Berg, P, Lingqvist, O (2017), "Pulp, paper, and packaging in the next decade: Transformational change", McKinsey \& Company: Paper \& Forest Products. April. Available at: https://www.mckinsey.com/industries/paper-and-forest-products/our-insights/pulp-paper-andpackaging-in-the-next-decade-transformational-change (Accessed 01 February 2018).

Biofore (2018), "Biofore Concept Car", UPM Company website, available at: http://www.upm.com/bioforeconceptcar/Pages/default.aspx (Accessed 10 January 2018).

Bioregional (2020), One Planet Living. Available at: https://www.bioregional.com/one-planetliving (Accessed 06 August 2020).

Bobiec, A., Gutowski, J., Laudenslayer, W., Pawlaczyk, P., Zub, K. (2005), The Afterlife of a Tree. WWF-Poland, Warsaw.

Bonan, G. (2008), "Forests and Climate Change: Forcings, Feedbacks, and the Climate Benefits of Forests", Science, Vol. 320, No. 5882, pp. 1444-14449.

Burivalova1, Z., Hua, F., Koh, L., Garcia, C., Putz, F. (2017), “A Critical Comparison of Conventional, Certified, and Community Management of Tropical Forests for Timber in Terms of Environmental, Economic, and Social Variables", Conservation Letters, Vol. 10, No. 1, pp. 4-14.

CaReWood (2015), CaReWood: Cascading Recovered Wood - A European project to innovatively recapture, reuse and recycle wood products. Project website. Available at: http://carewood.eu/ (Accessed 17 September 2015).

Carus, M. (2017), "Biobased Economy and Climate Change-Important Links, Pitfalls, and Opportunities", Industrial Biotechnology, Vol. 13, No. 2, pp. 41-51.

Carus, M. et al. (2014), Environmental Innovation Policy - Greater resource efficiency and climate protection through the sustainable material use of biomass - Short version. Texte, March 2014. Umweltbundesamt (German Federal Agency for the Environment), Berlin.

Cashore, F., Gale, F., Meidinger, E., Newsom, D. (2006), "Forest Certification in Developing and Transitioning Countries: Part of a Sustainable Future?", Environment: Science and Policy for Sustainable Development, Vol. 48, No. 9, pp. 6-25.

CEPI (2011), Unfold the Future - The Forest Fibre Industry: 2050 Roadmap to a low-carbon bioeconomy, Confederation of European Paper Industries, Brussels.

Charonis, G. (2012), "Degrowth, steady state economics and the circular economy: three distinct yet increasingly converging alternative discourses to economic growth for achieving environmental sustainability and social equity", World Economy Association Sustainability Conference 2012.

de Jesus, et al. (2017), "Eco-innovation in the transition to a circular economy: An analytical literature review", Journal of Cleaner Production, Vol. 172, pp. 2999-3018 (20 January 2018) Available at: https://doi.org/10.1016/j.jclepro.2017.11.111 (Accessed January 2018). 
Denier, L et al (2015), The Little Sustainable Landscapes Book: Achieving sustainable development through integrated landscape management, Global Canopy Programme, Oxford.

Desing, H. et al (2020), "A circular economy within the planetary boundaries: Towards a resourcebased, systemic approach", Resources, Conservation \& Recycling, Vol. 155, pp. 1-14.

Dudley, N., Vallauri, D (2004), WWF Report: Deadwood - Living forests, WWF-International, Gland, Switzerland.

EFM (2018), Internet site. Ecotrust Forest Management (EFM). Available at: http://www.ecotrustforests.com (Accessed 10 February 2018).

Elkington, J (1997), Cannibals with Forks: the Triple Bottom Line of the $21^{\text {st }}$ Century, Capstone, Oxford.

Elkington, J. and Beloe, S. (2007), One Planet Business: Creating value within planetary limits, SustainAbility, London.

EMF (2013a), Towards the circular economy: Economic and business rationale for an accelerated transition, Vol. 1, Ellen MacArthur Foundation, Cowles, UK.

EMF (2013b), Towards the circular economy: Opportunities for the Consumer Goods Sector, Vol. 2,Ellen MacArthur Foundation, Cowles, UK.

EMF (2014), Towards the circular economy: Accelerating the scale-up across global supply chains, Vol. 3, Ellen MacArthur Foundation, Cowles, UK.

EMF (2015a), Growth Within: a circular economy vision for a competitive Europe, Ellen MacArthur Foundation, Cowles, UK.

EMF (2015b), Delivering the circular economy: a toolkit for policymakers, Ellen MacArthur Foundation, Cowles, UK.

EMF (2017), Achieving 'Growth Within’, Ellen MacArthur Foundation, Cowles, UK.

EMF (2018). Circular Economy Systems Diagram, Ellen MacArthur Foundation Website, Available at: https://www.ellenmacarthurfoundation.org/circular-economy/interactive-diagram (Accessed 03 March 2018).

Enters, T. (2001), Trash or Treasure? Logging and mill residue in Asia and Pacific, FAO Regional Office for Asia and the Pacific.

Enviroportal (2016), "Ťažba dreva" (Wood harvesting), posted 22 November. Information portal of the Slovak Ministry of Environment. Available at:

https://www.enviroportal.sk/indicator/detail?id=781 (Accessed 03 March 2018).

EPEA Nederland BV, SundaHus i Linköping AB (2017), Framework for Materials Passports. Report for Buildings as Materials Banks project. Available at: http://www.bamb2020.eu/wpcontent/uploads/2018/01/Framework-for-Materials-Passports-for-the-webb.pdf (Accessed 17 February 2018).

Espinoza, O., Laguarda-Mallo, M. (2016), "Innovation in the Forest Products Industry", Extension January 01. Available at: http://articles.extension.org/pages/68071/innovation-in-the-forest-productsindustry (Accessed on 01 February 2018).

European Commission (2011), Energy roadmap 2050 (COM(2011) 885 final of 15 December. European Commission, Brussels.

European Commission (2015), Closing the Loop - an EU Action Plan for the circular economy. Com(2015) 614 Communication from the Commission to the European Parliament, the Council, the European Economic and Social Committee and the Committee of the Region. European

Commission, Brussels. 
Extension (2015), "Basics of Cross Lamited Timber (CLT)", Extension, January 30. Available at: http://articles.extension.org/pages/67367/basics-of-cross-lamited-timber-clt (Accessed 01 February $\underline{2018}$.

FAO (2009), How to Feed the World in 2050, Food and Agriculture Organisation, Rome.

Faraqi, S et al (2018), The Business of Planting Trees: A growing investment opportunity, World Resources Institute and The Nature Conservancy, Washington, D.C.

Ferguson, W. (2012), "Why wood pulp is world's new wonder material", New Scientist, 23 August 2012. Available at: https://www.newscientist.com/article/mg21528786-100-why-wood-pulp-isworlds-new-wonder-material/ (Accessed 17 February 2018).

FSC (2018), Website of the Forest Stewardship Council (FSC). Available at: https://ic.fsc.org/ (Accesssed 14 February 2018).

FSC-Watch (2018), Internet site: FSC-Watch, Available at: https://fsc-watch.com/ (Accessed 14 February 2018).

Geng, Y. and Doberstein, B. (2008) Developing the circular economy in China: Challenges and opportunities for achieving 'leapfrog development'. The International Journal of Sustainable Development \& World Ecology 15(3), 231-239.

Geissdoerfer, M., Savaget, P., Bocken, N., Hultink, E. (2017), The circular economy - A new sustainability paradigm? Journal of Cleaner Production, 143: 757-768.

Ghisellini, P., Cialani, C., Ulgiati, S. (2016), "A review on circular economy: the expected transition to a balanced interplay of environmental and economic systems", Journal of Cleaner Production, Vol. 114, pp. 11-32.

Global Forest Watch (2018), Interactive map powered by Google maps - Forest cover for Slovakia. Global Forest Watch. Available at:

http://www.globalforestwatch.org/map/7/48.29/19.37/SVK/grayscale/forest2010?tab=analysistab\&threshold=25\&dont_analyze=true (Accessed 3 March 2018).

Godina, L. (2016), "Slovenia is moving towards a circular economy", Circulate (www.circulatenews.org) January 9 2016. Available at: http://circulatenews.org/2016/01/slovenia-ismoving-towards-a-circular-economy/ (Accessed 15 February 2018).

Greenpeace (2014), "Weaker Certification Schemes: Other forest industry driven certification schemes fail to meet basic performance indicators". Greenpeace International Internet Site, 3 March 2014. Greenpeace International, Amsterdam. Available at: https://www.greenpeace.org/archiveinternational/en/campaigns/forests/solutions/alternatives-to-forest-destruc/Weaker-CertificationSchemes/ (Accessed 16 February 2018).

Gulbrandsen, L. (2004) "Overlapping Public and Private Governance: Can Forest Certification Fill the Gaps in the Global Forest Regime?", Global Environmental Politics, Vol. 4, No. 2, pp. 75-99.

Gunningham, N., Sinclair, D. (2002), "Voluntary Approaches to Environmental Protection: Lessons from the Mining and Forestry Sectors", OECD Global Forum on International Investment, 7-8 February 2002, OECD, Paris.

Houdini (2018), Our reason to exist: Houdini Planetary Boundaries Assessment 2018. Available at: https://houdinisportswear.com/en-se/sustainability/planetary-boundaries-assessment (Accessed 06 August 2020).

IKEA (2018), "Forestry and Wood" (IKEA Internet site). Inter-IKEA Systems B.V., Delft, Netherlands. Available at:

http://www.ikea.com/ms/en_AU/about_ikea/our_responsibility/forestry_and_wood/index.html (Accessed 16 February 2018).

Kapitán, P. (2017), "Ecocide! How Slovakia destroys its national parks", Slovak Spectator, 16 November 2017. 
Keith, H, Mackey, B., Lindenmayer, D. (2009), "Re-evaluation of forest biomass carbon stocks and lessons from the world's most carbon-dense forests", Proceedings of the National Academy of Sciences, Vol. 106, No. 28, pp. 11635-11640.

Kingfisher (2013), The business opportunity of closed loop innovation: Kingfisher's progress towards products that waste nothing. Kingfisher, London. Available at: Kingfisher.co.uk (Accessed 18 January 2018).

Korhonen, J., Honkasalo, A., Seppälä, J. (2018), "Circular Economy: The Concept and its Limitations", Ecological Economics, Vol. 143, pp. 37-46.

Kovalčík, M (2014), "Value of forest berries and mushrooms picking in Slovakia's forests”, Faculty of Forestry and Wood Technology, Mendel University of Agriculture and Forestry, Division of Scientific Information (Vysoka Skola Zemedelska v Brne, Lesnicka Fakulta), Brno, Czech Republic.

Kronospan (2018), "FSC, PEFC Certification" - on Kronospan Internet site. Kronospan. Available at: http://www.kronospan-worldwide.com/environment/fsc-pefc-and-certification/ (Accessed 14 February 2018).

Larsson, P. (2014), "Wood fibres stronger than steel. Bio-based Press", posted 30 June 2014. Available at: https://www.biobasedpress.eu/2014/06/wood-fibres-stronger-steel/ (Accessed on 1 February 2018).

Lavoine, N.; Desloges, I.; Dufresne, A.; Bras, J. (2012), "Microfibrillated cellulose - its barrier properties and applications in cellulosic materials: a review", Carbohydrate Polymers, Vol. 90, No. 2, pp. 735-64.

Li, Y. and Ma, C. (2015), "Circular economy of a papermaking park in China: a case study", Journal of Clean Production, Vol. 92, pp. 65-74.

Lieder, M. and Rashid, A. (2016), "Towards circular economy implementation: a comprehensive review in context of manufacturing industry", Journal of Cleaner Production, Vol. 115, pp. 36-51.

Luke (2018), "Customer Solutions - Circular Solutions and Sustainability" (Internet site). Natural Resources Institute Finland (Luke), Helsinki. https://www.luke.fi/en/business-solutions/expertiseareas/circular-economy-sustainability/ (Accessed January 2018).

Lyon, T. (2013), "The Pros and Cons of Voluntary Approaches to Environmental Regulation. Reflections on Responsible Regulation Conference", Tulane University, March 1-2, 2013.

Mabee, W. (2011), "Circular Economies and Canada's Forest Sector. Work in a Warming World: Working Paper \#2011-08”, Researchers' Workshop: “Greening Work in a Chilly Climate”, Toronto, November 2011.

Mantau, U., Saal, U., Prins, K., Steierer, F., Lindner, M., Verkerk, H., Eggers, J., Leek, N., Oldenburger, J., Asikainen, A., Anttila, P. (2010), EUwood - Real potential for changes in growth and use of EU forests. Final report,University of Hamburg - Centre of Wood Science, Hamburg.

McCarthy, J., Canziana, O., Leary, N., Dokken, D., White, K. (2001), Climate Change 2001: impacts, adaptation, and vulnerability: contribution of Working Group II to the third assessment report of the Intergovernmental Panel on Climate Change, Cambridge University Press, Cambridge.

Merli, R., Preziosi, M., Acampora, A. (2018) How do scholars approach the circular economy? A systematic literature review. Journal of Cleaner Production (Accepted Manuscript), doi: 10.106/j.jclepro.2017.12.112.

Mikoláš, M., Tejkal, M., Kuemmerle, T., Griffiths, P., Svoboda, M., Hlásny, T., Leitão, P.J., \& Morrissey, R.C. (2017), "Forest management impacts on capercaillie (Tetrao urogallus) habitat distribution and connectivity in the Carpathians", Landscape Ecology, Vol. 32, No.. 163.

Ministry of Environment (2014), Adaptation Strategy of the Slovak Republic on Adverse Impacts of Climate Change Overview: Executive Summary, Ministry of Environment of the Slovak Republic, Bratislava. 
Mondi (2017), Mondi Group Sustainable development report 2016. Mondi Group, Addlestone', UK. . Available at: http://reports2016.mondigroup.com/downloads/sustainable-development-report2016.pdf (Accessed 17 February 2018).

Moore, S., Cubbage, F., Eicheldinger, C. (2012), "Impacts of Forest Stewardship Council (FSC) and Sustainable Forestry Initiative (SFI) Forest Certification in North America", Journal of Forestry, Vol. 110, No. 2, pp. 79-88.

MunichRe (2018), "Natural catastrophe review: Series of hurricanes makes 2017 year of highest insured losses ever" (Press Release). Munich RE, 4 January 2018. Available at: https://www.munichre.com/en/media-relations/publications/press-releases/2018/2018-01-04-pressrelease/index.html (Accessed 3 February 2018).

Murray, A., Skene, K. and Haynes, K. (2015), "The circular economy: An interdisciplinary exploration of the concept and application in a global context", Journal of Business Ethics, Vol. 140, No. 3, pp. 369-380.

Myers, M. (2013), Qualitative Research in Business \& Management, $2^{\text {nd }}$ ed. SAGE, Los Angeles.

My jsme les (2018), "My jsme les" ("We are the forest") - Internet site of campaign. Available at: https://www.mysmeles.sk/kto-sme (Accessed 9 February).

National Forest Centre (NFC) (2017), Report on the Forest Sector of the Slovak Republic 2016 GREEN REPORT, Slovak Ministry of Agriculture, Bratislava.

Nave, L.E., Vance, E.D., Swanston, C.W. and Curtis, P.S. (2010), "Harvest impacts on soil carbon storage in temperate forests", Forest Ecology and Management, Vol. 259, pp. 857-866.

Nordstrom, P, O’Kelly, G (2013), “Tighter recycled fiber markets: Softwood strikes back!”, McKinsey on Paper. 2013 Vol. 3. Available at:

https://www.mckinsey.com/ /media/McKinsey/Industries/Paper\%20and\%20Forest\%20Products/Our $\% 20$ Insights/Tighter\%20recycled\%20fiber\%20markets/Tighter\%20recycled\%20fiber\%20markets.as hx (Accessed 02 February 2018).

O’Brien, M., Wechsler, D., Bringezu, S. and Schaldacher, R. (2016), “Toward a systemic monitoring of the European bioeconomy: Gaps, needs and the integration of sustainability indicators and targets for global land use", Land Use Policy, Vol. 66, pp. 162-171.

OECD (2010), "Material Case Study 3: Wood Fibres (Working Document)", OECD Global Forum on Environment Focusing on Sustainable Materials Management, 25-27 October in Mechelen, Belgium. OECD Environment Directorate, Paris. Available at: https://www.oecd.org/env/waste/46102448.pdf (Accessed 20 January 2018).

OECD (2012), OECD Environmental Outlook to 2050, Organisation for Economic Co-operation and Development, Paris.

Pakarinen, S., Mattila, T., Melanen, M., Nissinen, A. and Sokkla, L. (2010), "Sustainability and industrial symbiosis - the evolution of a Finnish forest industry complex", Resource Conservation Recycling, Vol. 54, No. 12, pp. 1393-404.

Patterson, T. and Coelho, D. (2009), "Ecosystem services: Foundations, opportunities, and challenges for the forest products sector", Forest Ecology and Management, Vol. 257, pp. 16371646.

Patwa, N., Sivarajah, U., Seetharaman, A., Sarkar, S., Maiti, K., \& Hingorani, K. (2020). Towards a circular economy: An emerging economies context. Journal of Business Research.

https://doi.org/10.1016/j.jbusres.2020.05.015

Peters, G.P., Weber, C.L., Guan, D. and Hubacek, K. (2007) China's growing CO2 emissions: A race between increasing consumption and efficiency gains. Environmental Science and Technology 41(17), 5939-5944. 
PEFC (2018), Who we are - Internet site of the Programme for the Endorsement of Forest Certification (PEFC). Available at: http://www.pefc.org/about-pefc/who-we-are (Accessed 10 February 2018).

Poyry (2012), "Future from Fibre: From Forest to Finished Product", Technical Paper for the World Business Council on Sustainable Development and WWF-International, World Business Council on Sustainable Development, Geneva.

Price Waterhouse Coopers (PWC) (2010), Life Cycle Assessment and Forest Products: A White Paper, September. Forest Products Association of Canada, Ottawa.

Ramage, M., Burridge, H., Busse-Wicher, M., Feredaya, G., Reynolds, T., Shah, D., Wu, G. Yuc, L., Fleming, P., Densley-Tingleye, D. Allwood, J., Dupree, P., Linden, P., Scherman, O. (2017), "The wood from the trees: The use of timber in construction." Renewable and Sustainable Energy Reviews, Vol. 68, pp. 333-359.

Rockström, et al. (2009), "Planetary boundaries: exploring the safe operating space for humanity", Ecology and Society, Vol. 14, No. 2, pp. 32.

Saunders, M., Lewis, P., Thornhill, A. (2012), Research methods for business students (6th edition). Pearson, Harlow, UK.

Science Based Targets (2020), Website. Available at: https://sciencebasedtargets.org/ (Accessed on 06 August 2020)

Science Based Targets Network (2020), Website. Available at:

https://sciencebasedtargetsnetwork.org/ (Accessed on 06 August 2020).

Seibold, S., Bässlera, C., Brandl, R., Gossner, M., Thorn, S., Ulyshend, M. and Müller, J. (2015), "Experimental studies of dead-wood biodiversity - A review identifying global gaps in knowledge", Biological Conservation, Vol. 191, pp. 139-149.

Sitra (2016a), "The opportunities of a circular economy for Finland", Sitra Studies 100 (October 2015).Sitra (Finnish Innovation Fund), Helsinki.

Sitra (2016b), "Leading the cycle: Finnish road map to a circular economy 2016-2025". Sitra Studies 121.Sitra (Finnish Innovation Fund), Helsinki.

Skog K. and Nicholson, G. (1998), "Carbon cycling through wood products: the role of wood and paper products in carbon sequestration”, Forest Products Journal, Vol. 48, No. 7-8, pp. 75-83.

Slovak Ministry of Environment (2010), State of the Environment of the Slovak Republic 2010. Ministry of Environment of the Slovak Republic, Bratislava.

Slovak Ministry of Environment (2020), Green Circular Economy (Internet page). Available at: https://www.minzp.sk/en/areas/green-circular-economy/ (Accessed on 8 August 2020).

Steffen, W., Richardson, K., Rockström, R., Cornell, S., Fetzer, I., Bennett, E., Biggs, R., Carpenter, S., de Vries, W., de Wit, C., Folke, C., Gerten, D., Heinke, J., Mace, G., Persson, L. Ramanathan, V., Reyers, B., and Sörlin, S. (2015), "Planetary Boundaries: Guiding human development on a changing planet", Science 16 January 2015, Vol. 347, No. 6223.

Sokkla, L., Pakarinen, S., Melanen, M. (2011), "Industrial symbiosis contributing to more sustainable energy use - an example from the forest industry in Kymenlaakso, Finland", Journal of Clean Production, Vol. 19, No. 4, pp. 285-93.

Stinson, E. (2017), "Get Ready for Skyscrapers Made of Wood (Yes, Wood)”, Wired Magazine, May 30 2017. Available at: https://www.wired.com/2017/05/wood-skyscrapers/ (Accessed 03 February 2018).

Stora Enso (2016), "Lignin of tomorrow", Website Stora Enso, 29 January. Available at: http://www.storaenso.com/newsandmedia/lignin-of-tomorrow (Accessed 03 February 2018). 
TEEB (2012), The Economics of Ecosystems and Biodiversity in Business and Enterprise. Edited by Joshua Bishop.Earthscan, London.

Theodora (2017), Countries of the World: Slovakia. Theodora.com. Updated 12 January. Available at: https://theodora.com/wfbcurrent/slovakia/slovakia_economy.html (Accessed 3 February 2018).

UNECE (2017), The Slovak National Market Report 2017: Timber. United Nations Economic Council for Europe, Geneva. Available at: https://www.unece.org/fileadmin/DAM/timber/countryinfo/statements/slovakia2017.pdf (Accessed 3 February 2018).

UNECE (2014), Rovaniemi Action Plan for the Forest Sector in a Green Economy: Geneva Timber and Forest Study Paper 35. UNECE/FAO Forestry and Timber Section, UNECE, Geneva.

UNIDO (2017), “Auto industry's shift towards a circular economy focus of international conference in Slovakia". Press Release, 6 November 2017, United Nations Industrial Development Organisation (UNIDO), Vienna. Available at: https://www.unido.org/news/auto-industrys-shift-towards-circulareconomy-focus-international-conference-slovakia (Accessed 6 February 2018).

UPM (2018), Company Website. UPM, Helsinki. Available at: http://www.upm.com/Aboutus/Pages/default.aspx (Accessed January 2018).

Vis, M., Mantau, B., Allen, B. (Eds) (2016), CASCADES - Study on the optimised cascading use of wood. No 394/PP/ENT/RCH/14/7689. Final Report. European Commission, Brussels.

Vlk (2013), "Spracovanie biomasy v regióne východného Slovenska vo vzt’ahu k zachovaniu prirodzených lesov" (Processing of biomass in the region of Eastern Slovakia with regard to conservation of natural forests). Vlk (WOLF Forest Protection Movement), Tulčík, Slovakia. English summary: Use of wooden biomass for energy purposes in Slovakia. Available online:

https://biomasaker.wolf.sk/files/BIOMASAKER sumar_EN.pdf (Accessed 17 February 2018).

Walter, M. (2008), Analysis of the FSC and PEFC Systems for Forest Management Certification using the Forest Certification Assessment Guide (FCAG). Available at:

http://awsassets.panda.org/downloads/2008_11_17_final_fcag_assessment_.pdf (Accessed 10 February 2019).

Waste and Resources Action Programme (WRAP), (2011) A Methodology for Quantifying the Environmental and Economic Impacts of Reuse. WRAP.

http://www.wrap.org.uk/sites/files/wrap/Final\%20Reuse\%20Method.pdf. Accessed 15 January 2019.

Wijkmann, A. and Skanberg, K. (2015), The circular economy and Benefits for Society: Jobs and Climate Clear Winners in an Economy Based on Renewable Energy and Resource Efficiency, The Club of Rome, Winterthur, Switzerland.

Winans, K., Kendall, A. and Deng, H (2017), "The history and current applications of the circular economy concept", Renewable and Sustainable Energy Reviews, Vol. 68, pp. 825-833.

WTTC (2017), Travel and Tourism: Economic Impact 2017 - Slovakia. World Travel and Tourism Council.

WWF (2011), Forests for a Living Planet: WWF Living Forests Report-Chapter 1. WWF International, Gland, Switzerland.

WWF (2012), Forests and Wood Products: WWF Living Forests Report - Chapter 4. WWF International, Gland, Switzerland.

WWF (2015), "WWF Forest Certification Assessment Tool (CAT) - including results for FSC, PEFC. Internet site", posted 18 May 2015.WWF-International, Gland, Switzerland. Available at: http://wwf.panda.org/wwf_news/?246871/WWF-Forest-Certification-Assessment-Tool-CAT (Accessed 16 February 2018).

WWF (2016), Living Planet Report, WWF International, Gland, Switzerland. 
WWF-DCP (2018), WWF Danube-Carpathian Programme - Internet site. Available at: http://wwf.panda.org/what_we_do/where_we_work/black_sea_basin/danube_carpathian/ (Accessed 16 February 2018).

WWF-DCP (2019) How can we make sustainable landscapes pay?: Workshop on Landscape Finance and Slovak Forests, 22 March 2019 (unpublished workshop report).

Yin, R. (2009), Case Study Records: Design and Methods (4th ed), Sage, Thousand Oaks, CA.

Yuan, Z., Bi, J. and Moriguichi, Y. (2006) The circular economy: a new development strategy in China. Journal of Industrial Ecology, Vol. 10, No. 1-2, pp. 4-8.

Zeleňáková, M and Z. Vranayová (2015), "Flood damages in Slovakia. Recent Advances in Environmental and Earth Sciences and Economics", Zakynthos Conference (20 July 2015). Available at: http://www.inase.org/library/2015/zakynthos/bypaper/ENG/ENG-33.pdf (Accessed 06 February 2018). 